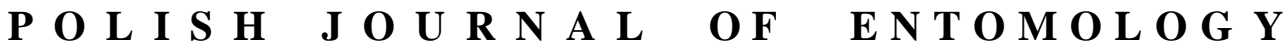

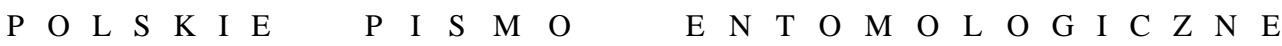

VOL. 87: 77-84

Lublin

31 March 2018

DOI: $10.2478 /$ pjen-2018-0006

\section{Circadian variation in metabolite and enzyme activities in the femoral and thoracic muscles of adult variegated grasshoppers, Zonocerus variegatus (LINNAEUS, 1758) (Orthoptera: Pyrgomorphidae)}

\author{
Kehinde Olutoyin Ademolu ${ }^{1 *}$, SAMUEl AgBeje ${ }^{1}$, \\ ABIODUN OLADIPUPO JODA ${ }^{2}$, ADEBOLA ADEDOYIN OSIPITAN ${ }^{3}$, \\ ADEWUNMI BATABUNDE IDOWU ${ }^{1}$ \\ ${ }^{1}$ Department of Pure and Applied Zoology, Federal University of Agriculture, \\ Abeokuta, Nigeria \\ ${ }^{2}$ Department of Crop Production, Olabisi Onabanjo University, Ayetooro, Nigeria \\ ${ }^{3}$ Department of Crop Protection, Federal University of Agriculture, Abeokuta, Nigeria
}

\begin{abstract}
The African variegated grasshopper, Zonocerus variegatus, exhibits daily variations in its feeding and destructive activities. A study to investigate circadian variation in metabolites (lipids, protein, glucose, $\mathrm{K}^{+}, \mathrm{Ca}^{2+}, \mathrm{Mg}^{2+}, \mathrm{Cl}^{-}$) concentrations and enzymes (lipase, amylase, proteinase, $\alpha$-glucosidase) activities in the femoral and thoracic muscles of adult $Z$. variegatus was carried out by collecting samples at 06:00, 12:00, 18:00 and 24:00 hrs GMT. The four enzymes were present throughout the day in both thoracic and femoral muscles but at varying levels. Significantly $(\mathrm{p}<0.05)$ higher enzymes activities were measured during the day (between 06:00 and 18:00 hours GMT) (except proteinase) than at night (24:00 hrs). Organic substances in the two tissues were present in significantly higher concentrations during the day than at night. Similarly, significantly more inorganic substances were recorded in the afternoon (12:00-18:00 hrs) than at night in both femoral and thoracic muscles. It can thus be concluded that locomotor activities in $Z$. variegatus reach a peak during the day.
\end{abstract}

KEY WORDS: circadian, Zonocerus variegatus, femoral muscles, thoracic muscles, enzymes.

*Corresponding author: kennyademolu@yahoo.com 


\section{INTRODUCTION}

The African grasshopper, Zonocerus variegatus (LinNAEUS, 1758) is a polyphagous insect that consumes many plant species (TOYE 1982). ChIFFAUd \& MESTRE (1970) reported that $Z$. variegatus consumes more than 250 plants including citrus, cocoa, banana, vegetables and cassava. However, this insect exhibits food preferences during its life cycle. The early stages $\left(1^{\text {st }}-3^{\text {rd }}\right.$ instars) survive on weeds like Chromolaena odorata (L.) R.M.KING \& H.ROB., Talinum triangulaire (L.). Juss., Aspilia latifolia OLIV. \& HIERN and Tridax procumbens $(\mathrm{L}$.$) , whereas the later instars \left(4^{\text {th }}-6^{\text {th }}\right)$ and adult stage prefer cassava leaves (Manihot esculenta MILL.) (TOYE 1974).

In their description and morphometry of Z. variegatus nymphs, CHAPMAN et al. (1977) stated that body sizes increased in length and weight throughout its life cycle. More recently, ADEMOLU et al. (2013a) observed that the size and body weight of Z. variegatus increased progressively during post-embryonic development and that there was a strong positive relationship between body length and body weight on the one hand and between body weight and antennal length on the other. Similarly, the length, width and weight of the hind femur of $Z$. variegatus increased during post-embryonic development (ADEMOLU et al. 2009).

Thoracic and femoral muscles play a major role in the dispersive abilities of $Z$. variegatus. The survival of grasshoppers depends on their abilitities to hop and fly which are facilitated by the two tissues. Diets were reported to have a significant effect on the insect's flight activities as they influenced the enzymatic activities of both femoral and thoracic muscles (ADEMOLU et al. 2013b).

In $Z$. variegatus, the muscles of the hind femur grow throughout the instar stages, but cease doing so just before and during the period of ecdysis (HILL \& GOLDSWORTH 1968). Similarly, protein, lipid and glucose concentrations in the femoral muscles were found to increase throughout post-embryonic development and were significantly higher in the femoral muscles than in fat body and haemolymph (OLADIRAN 1991, ADEMOLU et al. 2007).

MODDER (1984) reported a diurnal variation in the feeding and gut activities in nymphs of $Z$. variegatus, with the insect feeding most intensively at 13:00 hrs and having the lowest midgut $\alpha$ - and $\beta$-glucosidase activities at 12:00 and 19:00 hrs. However, the pattern of daily enzymes activities in the femoral and thoracic muscles (the tissues responsible for locomotion) of $Z$. variegatus has not received any attention in the literature. Hence, the main aim of this study is to investigate daily variation in the metabolite concentrations and enzyme activities in the femoral and thoracic muscles of adult $Z$. variegatus. 


\section{MATERIALS AND METHODS}

\section{Insect Collection and Maintenance}

Penultimate $\left(6^{\text {th }}\right)$ instar nymphs of $Z$. variegatus were collected from uncultivated farmland within the campus of the Federal University of Agriculture, Abeokuta (FUNAAB), Nigeria in the early hours of the day (6:30-7:30 hrs GMT). The insects were brought to the insectary of the Department of Pure and Applied Zoology, FUNAAB (ambient temperature $27.0 \pm 0.05{ }^{\circ} \mathrm{C}$, relative humidity $65-70 \%$ and $12 \mathrm{D}: 12 \mathrm{~L}$ ) where they were sorted into males and females. Only males were used for this experiment and were maintained on cassava leaves (Manihot esculenta) until the emergence of the adult stage. Two days after adult emergence, 150 individuals were picked out for the experiment. Twenty-five insects were taken out of the pool at different times of the day, namely: 06:00, 12:00, 18:00 and 24:00 hrs GMT (MODDER 1984). They were immobilized by placing them in a freezer $\left(-10^{\circ} \mathrm{C}\right)$ for 4 hours before dissection.

\section{Sample Preparation}

The muscles of the hind femur of the selected insects were removed with forceps, placed in a test tube and homogenized in $0.05 \mathrm{M} \mathrm{KCl}$. The homogenates were centrifuged at $500 \mathrm{rpm}$ at $5{ }^{\circ} \mathrm{C}$ for 30 minutes. The supernatants were collected into a $30 \mathrm{ml}$ centrifuge bottle and stored in to a deep freezer $\left(-30^{\circ} \mathrm{C}\right)$ until further analysis.

The thoracic muscles of the same insects were dissected and removed by using methods described by MODDER (1981). The thoracic muscles were separated from the fat body, rinsed in water and then homogenized in $0.05 \mathrm{M} \mathrm{KCl}$ for 15 seconds using an electric glass blender (Roka). The homogenates were centrifuged at $500 \mathrm{rpm}$ at $5{ }^{\circ} \mathrm{C}$. The supernatant was collected into a $30 \mathrm{ml}$ bottle and stored in a freezer at $-30{ }^{\circ} \mathrm{C}$ for further analysis.

\section{Chemical analysis}

\section{Enzyme Assay}

The activities of $\alpha$-glucosidase and amylase in the femoral and thoracic muscles were determined following the methods of ADEDIRE \& BALOGUN (1995), while lipase and proteinase activities were assayed using ADEDIRE's (1994) protocols. The extracting buffer was $0.1 \mathrm{M}$ sodium hydrogen phosphate $(\mathrm{pH} 6.9)$. Five millilitres of the enzyme extract was added to $19 \mathrm{ml}$ of $2 \%$ casein solution and incubated at $35{ }^{\circ} \mathrm{C}$ for $30 \mathrm{~min}$. The mixture was filtered through Whatman No. 1 filter paper. A standard proteinase solution was prepared and treated as above. The absorbance of the sample and the standard proteinase filtrates were read off at a wavelength of $275 \mathrm{~nm}$. Proteinase activity was measured as the amount of proteinase capable of catalysing an absorbance change of 0.01 in $60 \mathrm{~s}$ at a wavelength of $275 \mathrm{~nm}$. All assays were carried out in triplicate. 


\section{Ionic Analysis}

The potassium $\left(\mathrm{K}^{+}\right)$concentration in the femoral and thoracic muscles was determined by Flame Photometry while calcium $\left(\mathrm{Ca}^{2+}\right)$ and magnesium $\left(\mathrm{Mg}^{2+}\right)$ were analysed using Atomic Absoption Spectrophotometry (AAS) (Model AA.403). Total chloride was assayed colourimetrically following the methods HENRY et al. (1974).

The total protein content of the thoracic and femoral muscles of adult Z.variegatus was determined by the Biuret method (HENRY et al. 1974) while the glucose content was estimated colourimetrically (BAUMNIGER 1974). GRANT's (1987) protocols were adopted for determining the lipid content.

\section{Statistical analysis}

One-way analysis of variance was used for the data analysis and the Student Newman Kuel test (SNK) was employed to separate significant means.

\section{RESULTS}

The enzymatic activities of the femoral and thoracic muscles of adult $Z$. variegatus at different times of the day are shown in Table 1: four enzymes (amylase, $\alpha$-glucosidase, proteinase and lipase) were detected at varying levels at these different times. Enzyme activities were the highest during daylight hours (06:00-18:00 hrs) and the least were recorded at midnight (24:00 hrs) (except proteinase). In addition, the enzyme activities were the highest and the lowest for $\alpha$-glucosidase (Table 1).

Table 1. Activities of enzymes (Abs/min)* in the femoral and thoracic muscles at different times of the day ( $\mathrm{n}=6)$. Enzymes: Lip. - Lipase, $\alpha$-gl. $-\alpha$-glucosidase, Am. - Amylase, Prot. - Proteinase.

\begin{tabular}{|c|c|c|c|c|c|c|c|c|}
\hline \multirow[t]{2}{*}{ Time of the day } & \multicolumn{4}{|c|}{ Femoral Muscles } & \multicolumn{4}{|c|}{ Thoracic muscles } \\
\hline & Lip. & $\alpha$-gl. & Am. & Prot. & Lip. & $\alpha$-gl. & Am. & Prot. \\
\hline 06:00 hrs & $\begin{array}{c}11.45 \\
\pm 0.03^{\mathrm{b}}\end{array}$ & $\begin{array}{c}9.81 \\
\pm 0.01^{\mathrm{a}}\end{array}$ & $\begin{array}{c}28.67 \\
\pm 0.01^{\mathrm{a}}\end{array}$ & $\begin{array}{c}17.12 \\
\pm 0.13^{\mathrm{a}}\end{array}$ & $\begin{array}{c}11.62 \\
\pm 0.21^{\mathrm{b}}\end{array}$ & $\begin{array}{c}9.78 \\
\pm 0.21^{\mathrm{a}}\end{array}$ & $\begin{array}{l}28.11 \\
\pm 0.02^{\mathrm{a}}\end{array}$ & $\begin{array}{c}11.45 \\
\pm 0.03^{\mathrm{b}}\end{array}$ \\
\hline $12: 00 \mathrm{hrs}$ & $\begin{array}{c}11.52 \\
\pm 0.01^{\mathrm{b}}\end{array}$ & $\begin{array}{c}9.71 \\
\pm 0.12^{\mathrm{a}}\end{array}$ & $\begin{array}{c}26.92 \\
\pm 0.21^{\mathrm{b}}\end{array}$ & $\begin{array}{c}17.62 \\
\pm 0.20^{\mathrm{a}}\end{array}$ & $\begin{array}{c}11.60 \\
\pm 0.03^{\mathrm{b}}\end{array}$ & $\begin{array}{c}9.65 \\
\pm 0.01^{\mathrm{a}}\end{array}$ & $\begin{array}{c}27.18 \\
\pm 0.01^{b}\end{array}$ & $\begin{array}{c}11.52 \\
\pm 0.01^{\mathrm{b}}\end{array}$ \\
\hline $18: 00 \mathrm{hrs}$ & $\begin{array}{l}12.11 \\
\pm 0.02^{\mathrm{a}}\end{array}$ & $\begin{array}{c}9.12 \\
\pm 0.11^{\mathrm{b}}\end{array}$ & $\begin{array}{c}26.48 \\
\pm 0.04^{\mathrm{b}}\end{array}$ & $\begin{array}{r}17.46 \\
\pm 0.11^{\mathrm{a}}\end{array}$ & $\begin{array}{c}12.36 \\
\pm 0.11^{\mathrm{a}}\end{array}$ & $\begin{array}{c}9.04 \\
\pm 0.13^{\mathrm{b}}\end{array}$ & $\begin{array}{l}26.85 \\
0.01^{\mathrm{c}}\end{array}$ & $\begin{array}{c}12.11 \\
\pm 0.02^{\mathrm{a}}\end{array}$ \\
\hline 24:00 hrs & $\begin{array}{c}12.27 \\
\pm 0.20^{\mathrm{a}}\end{array}$ & $\begin{array}{c}8.92 \\
\pm 0.03^{\mathrm{b}}\end{array}$ & $\begin{array}{c}26.11 \\
\pm 0.01^{\mathrm{b}}\end{array}$ & $\begin{array}{c}16.98 \\
\pm 0.01^{\mathrm{b}}\end{array}$ & $\begin{array}{c}12.44 \\
\pm 0.22^{\mathrm{a}}\end{array}$ & $\begin{array}{c}8.85 \\
\pm 0.01^{\mathrm{b}}\end{array}$ & $\begin{array}{l} \pm 26.22 \\
\pm 0.02^{\mathrm{c}}\end{array}$ & $\begin{array}{c}12.27 \\
\pm 0.20^{\mathrm{a}}\end{array}$ \\
\hline
\end{tabular}

*Mean values in the same column with the same superscript are not significantly different $(\mathrm{p}>0.05)$. 
Table 2 shows the organic metabolite concentrations in the thoracic and femoral muscles of adult $Z$. variegatus at different times of the day. Higher metabolite concentrations were measured early in the day (06:00 hrs) (except glucose) and protein concentrations ranked highest in the organic metabolites present in the two muscle tissues (42.56-48.92 g/l in femoral muscles and 42.97-49.12 g/l in thoracic muscles).

Table 2. Concentrations of organic metabolites in the femoral and thoracic muscles at different times of the day $(\mathrm{n}=6)$. Gl. - glucose $(\mathrm{mg} / \mathrm{dl})$, Pr. - protein (g/l), Lip. - Lipids $(\mathrm{mg} / \mathrm{dl})$.

\begin{tabular}{ccccccc}
\hline \multirow{2}{*}{$\begin{array}{c}\text { Time } \\
\text { of the day }\end{array}$} & \multicolumn{3}{c}{ Femoral Muscles } & \multicolumn{3}{c}{ Thoracic muscles } \\
\cline { 2 - 7 } & Gl. & Pr. & Lip. & Gl. & Pr. & Lip. \\
\hline 06:00 hrs & $12.46 \pm 0.02^{\mathrm{b}}$ & $48.92 \pm 0.01^{\mathrm{a}}$ & $9.89 \pm 0.012^{\mathrm{a}}$ & $12.12 \pm 0.22^{\mathrm{b}}$ & $49.12 \pm 0.12^{\mathrm{a}}$ & $9.91 \pm 0.03^{\mathrm{a}}$ \\
12:00 hrs & $12.68 \pm 0.04^{\mathrm{b}}$ & $42.56 \pm 0.01^{\mathrm{c}}$ & $9.11 \pm 0.04^{\mathrm{a}}$ & $12.74 \pm 0.02^{\mathrm{b}}$ & $42.97 \pm 0.04^{\mathrm{c}}$ & $9.01 \pm 0.02^{\mathrm{b}}$ \\
18:00 hrs & $12.96 \pm 0.015^{\mathrm{a}}$ & $46.75 \pm 0.03^{\mathrm{b}}$ & $8.96 \pm 0.01^{\mathrm{b}}$ & $12.94 \pm 0.10^{\mathrm{a}}$ & $46.92 \pm 0.02^{\mathrm{b}}$ & $8.90 \pm 0.01^{\mathrm{c}}$ \\
24:00 hrs & $13.11 \pm 0.01^{\mathrm{a}}$ & $47.11 \pm 0.02^{\mathrm{ab}}$ & $8.92 \pm 0.03^{\mathrm{b}}$ & $13.04 \pm 0.20^{\mathrm{a}}$ & $47.52 \pm 0.13^{\mathrm{b}}$ & $8.84 \pm 0.11^{\mathrm{c}}$ \\
\hline *Mean values in the same column with the same superscript are not significantly different $(\mathrm{p}>0.05)$.
\end{tabular}

Inorganic metabolites concentrations in the femoral and thoracic muscles sampled at different times of the day are presented in Table 3. These concentrations were affected by the time of day as the lowest concentrations were recorded during the early hours of the day. It is noteworthy that $\mathrm{Ca}^{2+}$ had the highest and $\mathrm{Cl}^{-}$the lowest concentration in the two muscle tissues.

Table 3. Concentrations of inorganic metabolites $(\mathrm{Mmol} / \mathrm{l})^{*}$ in the femoral and thoracic muscles at different times of the day $(n=6)$.

\begin{tabular}{lcccccccc}
\hline \multirow{2}{*}{ Time of the day } & \multicolumn{4}{c}{ Femoral Muscles } & \multicolumn{5}{c}{ Thoracic muscles } \\
\cline { 2 - 9 } & $\mathbf{C a}^{\mathbf{2 +}}$ & $\mathbf{K}^{+}$ & $\mathbf{M g}^{\mathbf{2 +}}$ & $\mathbf{C l}^{-}$ & $\mathbf{C a}^{\mathbf{2 +}}$ & $\mathbf{K}^{+}$ & $\mathbf{M g}^{\mathbf{2 +}}$ & $\mathbf{C l}^{-}$ \\
\hline \multirow{2}{*}{$06: 00 \mathrm{hrs}$} & 20.05 & 2.07 & 8.92 & 0.62 & 19.17 & 2.03 & 8.46 & 0.64 \\
& $\pm 0.01^{\mathrm{a}}$ & \pm 0.02 & $\pm 0.12^{\mathrm{a}}$ & \pm 0.13 & $\pm 0.12^{\mathrm{c}}$ & \pm 0.11 & $\pm 0.21^{\mathrm{b}}$ & $\pm 0.01^{\mathrm{b}}$ \\
\multirow{3}{*}{$12: 00 \mathrm{hrs}$} & 20.16 & 2.05 & 8.98 & 0.67 & 20.67 & 2.15 & 8.72 & 0.65 \\
& $\pm 0.13^{\mathrm{a}}$ & \pm 0.11 & $\pm 0.02^{\mathrm{a}}$ & \pm 0.02 & $\pm 0.01^{\mathrm{a}}$ & \pm 0.31 & $\pm 0.03^{\mathrm{a}}$ & $\pm 0.10^{\mathrm{b}}$ \\
\multirow{3}{*}{ 18:00 hrs } & 19.24 & 2.17 & 8.12 & 0.71 & 20.02 & 2.16 & 8.21 & 0.71 \\
& $\pm 0.02^{\mathrm{b}}$ & \pm 0.02 & $\pm 0.11^{\mathrm{b}}$ & \pm 0.04 & $\pm 0.03^{\mathrm{b}}$ & \pm 0.11 & $\pm 0.21^{\mathrm{b}}$ & $\pm 0.02^{\mathrm{a}}$ \\
\multirow{2}{*}{$24: 00 \mathrm{hrs}$} & 20.53 & 2.12 & 8.40 & 0.73 & 20.12 & 2.10 & 8.21 & 0.78 \\
& $\pm 0.12^{\mathrm{a}}$ & \pm 0.01 & $\pm 0.13^{\mathrm{b}}$ & \pm 0.12 & $\pm 0.34^{\mathrm{a}}$ & \pm 0.22 & $\pm 0.12^{\mathrm{b}}$ & $\pm 0.11^{\mathrm{a}}$ \\
\hline
\end{tabular}

*Mean values in the same column with the same superscript are not significantly different ( $p>0.05)$. 


\section{DISCUSSION}

Activities of amylase, $\alpha$-glucosidase, lipase and proteinase were measured in the thoracic and femoral muscles of adult Zonocerus variegatus at different times of the day. Similar enzymes were present in the thoracic and femoral muscles of $Z$. variegatus fed different food plants (ADEMOLU et al. 2013). MODDER (1981) detected similar enzymes in the thoracic muscles of Valanga irregularis (WALKER, 1870) (Orthoptera: Acrididae). The presence of these enzymes in the locomotor/dispersal tissues suggests that hydrolysis of the substrates is necessary for fuelling locomotion in the insect.

Comparison of mean values shows that amylase had the highest activity of all the enzymes detected in the two tissues. Amylase is essential in these two active tissues in order to hydrolyse stored glycogen to maltose and glucose which are assimilated in the body of Z. variegatus. This is a polyphagous insect consuming various food plants containing polysaccharide that require conversion to simpler carbohydrates before they can be utilized by the tissues (TOYE 1982). Amylase is the most important enzyme in many insects that feed exclusively on plants either during the larval stage or adult life (DARVISHZEDEH \& BANDANI 2012).

Higher enzyme activities (except proteinase) were observed during the daylight hours (06:00-18:00 hrs) in both femoral and thoracic muscles. This could be associated with the insect's diurnal behavior as it performs its feeding activities during the day, thus making substrate available for the enzymes to act upon. KAUFMAN (1965) reported that $Z$. variegatus feeds in the morning when the temperature is between $17{ }^{\circ} \mathrm{C}$ and $34{ }^{\circ} \mathrm{C}$ and roosts on food plants later in the evening. Similarly, MODDER (1984) concluded that gut motility and emptying peaked in the morning before noon (08:00-10:00 hrs) and in the afternoon (13:00-16:00 hrs).

Concentrations of organic metabolites in the two locomotor tissues were significantly higher in the afternoon than at night (except glucose). This reflects the time the metabolites need to fuel the tissues. Most flight and hopping activities of $Z$. variegatus take place in the afternoon in order to avoid predators, this is also when more food plants are consumed MODDER (1984). Lipids were earlier described as the fuel substrate in the thoracic and femoral muscles (ADEMOLU et al. 2013b) so their higher concentrations before noon will enhance the insect's flight capacity.

The results showed low concentrations of $\mathrm{Ca}^{2+}$ and $\mathrm{K}^{+}$around noon. The main function of $\mathrm{Ca}^{2+}$ and $\mathrm{K}^{+}$in the femoral muscles is effective nerve conduction and at low concentrations they enhance the activities of the muscle tissues, hence, these low concentrations at noon hours might be responsible for the more intensive movements or hopping activities of $Z$. variegatus in the afternoon, as earlier observed by TOYE (1982). 
Similar patterns of enzyme activities and metabolite concentration were observed in both femoral and thoracic muscles of $Z$. variegatus. The reason for this observation might first lie in their function, that is, both are involved in locomotion (hopping and flight) activities. Secondly, it might be that the food substrates that fuel these activities are mobilize from the haemolymph at the same time or at the same rate. It can be concluded that locomotor activity in $Z$. variegatus peaks during the day.

\section{REFERENCES}

ADEDIRE C.O. 1994. Distribution of carbohydrases and protease in the intestine of the Kola nut weevil, Sophrorhinus insperatus FAUST (Coleoptera: Curculionidae) and response of protease to inhibitor from Kola nuts. Applied Entomology and Zoology 29(3): 331-338.

Adedire C.O., BALOGun R.A. 1995. Digestive enzymes and regional localization of proteolytic endopeptidase in alimentary canal of Kola nut weevil, Sophrorhinus insperatus FAUST (Curculionidea). Entomon 20(3): 183-189.

Ademolu K.O., Idowu A.B., Amusan A.A.S. 2007. Chemical analysis of tissues of Zonocerus variegatus (L) (Orthoptera: Pyrgomorphidae) during post-embryonic development in Abeokuta, South-western Nigeria. Nigerian Journal of Entomology 24: 27-34.

Ademolu K.O., Idowu A.B., Olatunde G.O. 2009. Morphometrics and enzymes activities in the femoral muscles of variegated grasshopper, Zonocerus variegatus (Orthoptera: Pyrgomorphidae) during post embryonic development. International Journal of Tropical Insect Science 29(1): $53-56$.

Ademolu K.O., IdowU A.B., OKe O.A 2013a. Life cycle and morphometric studies of variegated grasshopper Zonocerus variegatus (LinNAEUS, 1758). Munis Entomology and Zoology 8(1): $375-381$.

Ademolu K.O., Idowu A.B., Onabiy O., OKe O.A. 2013b. The roles of food plants on the dispersion activities of variegated grasshopper, Zonocerus variegatus (L.) (Orthoptera: Pyrgomorphidae). African Entomology 21(1): 41-44.

BAumNiger R.M. 1974. Analytical Biochemistry. Oxford Press, London.

Chapman R.F., CoOK A.G., Mitchel, G.M., Page W.W. 1977. Description and morphometrics of the nymphs of Zonocerus variegatus (Orthoptera; Pyrgomorphidae). Bulletin of Entomological Research 67(3): 422-437.

ChiffAud J., Mestre J. 1990. Le criquet puant Zonocerus variegatus (LinNe, 1758): essai de synthese bibliographique. CIRAD-PRIFAS, Montpellier.

DARVISHZADEH A., BANDANI A.R. 2012. Identification and characterization of alpha-amylase in the Italian Locust, Calliptamus italicus (LinNAEus, 1758) (Orthoptera: Acrididae). Munis Entomology and Zoology 7(2): 1028-1034.

GRANT G.H 1987. Fundamentals of Clinical Chemistry. WB Saunders Company, Philadelphia.

Henry R.J., Canon D.C., Winkelman J.W 1974. Clinical Chemistry: Principles and Techniques. $2^{\text {nd }}$ ed. Harper and Row Publishers, New York. 
Hill L., Goldsworthy G.T. 1968. Growth, feeding activity and the utilization of reserves in larvae of Locusta. Journal of Insect Physiology 14(8): 1085-1098.

KAUFMAN T. 1965. Observations on aggregation, migration and feeding habits of Zonocerus variegatus (Orthoptera: Acrididae) in Ghana. Annals of the Entomological Society of America 58(4): $426-436$.

MODDER W.W.D. 1981. The glycosidases in the midgut and thoracic muscle of Valanga irregularis (WALKER) (Orthoptera: Acrididae). Acrida 10(2): 33-49.

MODDER W.W.D. 1984. Diurnal variation in the feeding and growth activity in nymphs of the African pest, grasshopper Zonocerus variegatus (L.). Insect Science and Application 5(6): 527-531.

OlADIRAN O.T. 1991. Aspects of the morphometrics of late instar and adult Zonocerus variegatus (L.) and the colorimetric absorbance due to protein content of their hind femur muscles. B.Sc. Project Report, University of Ibadan, Ibadan, Nigeria.

TOYE S.A. 1974. Feeding and locomotory activities of Zonocerus variegatus (L.) (Orthoptera, Acridoidea). Revue de Zoologie Africaine 88: 205-212.

TOYE S.A. 1982. Studies on the biology of the grasshopper pest Zonocerus variegatus (L.) (Orthoptera: yrgomorphidae) in Nigeria: 1911-1981. International Journal of Tropical Science 3(1): $1-7$.

Received: 24 July 2017

Accepted: 27 January 2018 